\title{
Arguing the case: Committing pregnant substance abusers to compulsory care
}

\author{
Therese Reitan ${ }^{1}$ \\ ${ }^{1}$ Centre for Social Research on Alcohol and Drugs (SoRAD), Stockholm University, S-106 91 Stockholm, Sweden
}

\begin{abstract}
Aims: To analyse how social services relate to compulsory care legislation in applications for compulsory care for substance abuse in cases involving pregnant women, given that such commitments cannot be made solely for the sake of the fetus/unborn child.

Design: Applications for compulsory care to administrative courts involving pregnant women categorized according to how the pregnancy was presented or emphasized.

Setting: Compulsory care for substance abuse in Sweden.

Participants: 116 cases involving 107 individuals who were pregnant at the time of application for commitment to compulsory care between 2000 and 2009.

Findings: In $43 \%$ of the cases the risks for both the woman and the fetus'/child's health was emphasized. In $28 \%$ of the cases the applications were primarily for the sake of the fetus/child. In $17 \%$ of the cases the pregnancy was mentioned in a neutral manner, while in $8 \%$ of the cases the fact that the woman was abusing substances during pregnancy was presented as an indication of the severity of the problem.

Conclusions: References were commonly made to the interests of the woman and the fetus/child as an entity, but social services also openly claimed the need for commitment primarily for the sake of the child. Arguments also mirrored the debate when legislation was first introduced; for example, that substance abuse during pregnancy is a clear indication of how serious the problem is, and how this situation may be hazardous to the woman's mental health should she become the cause of severe and irrevocable harm to her child.
\end{abstract}

Public policies and legislation have an important normative and symbolic value, but the journey from policy to practice may consist of a long and arduous implementation process where "great expectations in Washington are dashed in Oakland” (Pressman \& Wildavsky, 1984). At the operational level, we often find a street-level bureaucrat working in public services face-to-face with partly nonvoluntary clientele. Despite the surrounding bureaucratic structures, they typically enjoy a large degree of independence in work associated with discretion in decision-making (Lipsky, 1980). They may even be seen as the final implementors of public policy (Kelly, 1994). But, as resources usually are scarce and the workload demanding, street-level bureaucrats tend to develop coping mechanisms to relieve their work situation (Lipsky, 1980). Decision-making in street-level bureaucracies has attracted the attention of many social scientists, and the specific study of discrepancies between "law in the books and law in practice" became the core issue in the sociology of law (Staaf, 2004).

In Sweden, substance abuse has primarily been defined as a social problem, and commitments to compulsory care are in the hands of the street-level bureaucrats in the social services. Formally, the decision to apply for compulsory care rests with the municipal welfare boards, consisting of elected laypeople, which has meant that compulsory care became internalized in the Swedish welfare system (Palm \& Stenius, 2002). Compulsory care was, however, highly politicized as part of the pursuit of a "drug-free society," and welfare workers tended to oppose such coercive measures, actively and passively (Blomqvist, Palm, \& Storbjörk, 2009; Nilssen, 2007; Tham, 1995; Wallander \& Blomqvist, 2005). 
With broadly defined criteria, commitments to compulsory care are essentially based on discretion. To guide them, social workers have but a handful rulings from the Supreme Administrative Court, most of which are of procedural character (Svensson, 2012). Interpretation of the legislators' intents has therefore largely been confined to the proceedings from when the legislation was being drafted (Compulsory Care for Substance Abuse Bill 1981, No. 1981/82:8; Compulsory Care for Adult Substance Abusers Bill 1987, No. 1987/88:147; Swedish Government Official Report 1981, No. 1981/82:22; Swedish Government Official Report 1987b, No. 1987:22). Given its controversial character and that compulsory care has a direct and serious impact on individual integrity, its practice becomes inherently political and worth scrutinizing.

Some attempts have been made to study the influence of professional cultures and personal characteristics on decision-making in relation to compulsory care. In Sweden, it has, for example, been found that younger opiate abusers are more likely to be committed compared to older alcohol abusers, and that women and people with non-Swedish background are more likely to be committed compared to men and ethnic Swedes. Moreover, the rate of commitments varies substantially between municipalities with similar populations (Ekendahl, 1999, 2004; Johansson, 2001; Lundgren et al., 2012; Palm, 2009; Runquist, 2012; Storbjörk, 2003, 2010; Wallander \& Blomqvist, 2005).

\section{Compulsory Care for Pregnant Substance Abusers}

Risky or harmful use of alcohol and other substances among pregnant women has been a matter of concern among professionals and politicians for many years and has been the topic of a number of public inquiries and policy documents, both in Sweden and elsewhere (Parliamentary Committee of Social Affairs 1981, No. Ds S 1981:6; Ministry of Social Affairs 2009, No. Ds 2009:19; National Board of Health and Welfare, 2007a, 2007b; Swedish Government Official Report 1981, No. 1981/82:22; Swedish Government Official Report 1987a, No. 1987:11; Swedish Government Official Report 2005, No. 2005:82; Swedish Government Official Report 2011, No. 2011:35). The first comprehensive Swedish strategy on alcohol, drugs, doping, and tobacco was introduced in 2010 (Comprehensive Strategy for Alcohol, Drugs, Doping, and Tobacco Policy Bill 2010, No. 2010/11:47), mirroring an E.U. strategy from 2006 where reducing harm to born and unborn children was a prioritized goal (European Commission, 2006).

When the present compulsory care legislation was introduced in the early 1980s, the legislators faced the challenge of defining "severe" misuse of substances and, consequently, the "imperative need for care." In the case of pregnant women, it seemed easier; disregarding the consequences of continued substance abuse could hardly be regarded as normal behavior for a pregnant woman, and, if this behavior could not be ascribed to any other mental disorder, the addiction was probably so grave that it indicated an imperative need of care. Finally, there was a risk that a woman's own mental health would suffer if her abuse of substances should cause serious and irrevocable harms to the child (Swedish Government Official Report 1981, No. 1981/82:22).

In 2009 the conservative coalition government proposed a legislative amendment whereby pregnant substance abusers could be committed to compulsory care for the sake of the unborn child. The present legislation does mention "harm to significant others" among its criteria, but this does not include an unborn child (Compulsory Care for Adult Substance Abusers Bill 1987, No. 1987/88:147). The proposal was highly criticized and was not pursued. Perselli's (1998) conclusion, that it has not been possible to find a legal instrument that does not jeopardize the woman's right to her own body and to abortion and challenge the definition of a legal subject, is still valid.

The conflict between interests and clinical dilemmas are particularly salient in cases involving pregnant women. On the one hand, gender equality and women's rights have become a dominant norm in Swedish policy-making and society since the 1970s. Important steps in increasing women's rights, control of motherhood and reproduction, and equal opportunities in work and society include the abortion act in 1974, the introduction of paid parental leave to both parents in 1974, and the equal opportunities act in 1980. On the other hand, there is a strong tradition of promoting children's rights in Sweden. Swedish feminist and writer Ellen Key declared the twentieth century to be the century of the child and called for child-centered education and the abolition of corporal punishment. In 1979 , Sweden became the first country in the world to ban corporal punishment of any sort. Sweden was also a strong supporter of the Convention of the Right of the Child while it was being drafted and was one of the first countries to ratify the treaty in 1990 (Durrant, 1999; Eduards, 1991; Freeman, 2014; United Nations Children’s Fund, 2009).

Social workers facing pregnant substance abusers therefore encounter a conflict between the welfare of the "child to be" and the needs and rights of the woman. There are few studies on social work practice towards pregnant substance abusers, but in her study of applications for commitment during the 1990s, Staaf (2004) found that parental status, including pregnancy, was almost always mentioned in cases involving women. Two reports have focused specifically on pregnant clients and both have shown that commitments to compulsory care have in fact been made primarily out of concern for the unborn child (National Board of Health and Welfare, 2007a; Reitan \& Weding, 2012).

The aim of this article is, then, to describe how street-level bureaucrats translate "law in the books" into "law in practice," given that the fetus is not a legal subject and the pregnancy itself is not a valid criterion for compulsory care. How can social workers use their discretionary power to make their case? 


\section{Methods}

\section{Setting and Participants}

Compulsory care for substance abuse is provided solely by the National Board of Institutional Care (NBIC) in 11 institutions across Sweden. Around 1,000 adults are committed annually. Approximately one third are female.

The study set out to identify all documented or suspected pregnancies among women placed in compulsory care between 2000 and 2009. A variety of sources within the NBIC were searched in order to identify the relevant cases, including medical journals, registries and documentation systems, and consultations with staff at the institutions. The search rendered a total of 158 cases, of which 116 cases (107 individuals) where the pregnancy was known or suspected at the time of commitment were selected.

\section{Data}

Data were retrieved from client records and administrative registries, consisting of applications and assessments from the social services, court rulings, medical records, and in some instances structured client interviews at admission. Applications varied substantially in comprehensiveness and content; court rulings were fairly uniform in format but varied in length and detail.

\section{Document analysis}

The applications for compulsory care were coded independently by two persons into four categories based on the primary arguments for commitment: 1) those that claimed the risks for both the woman and the fetus, 2) those that claimed the risks for the fetus only, 3) those that argued for commitment with a neutral mentioning of the pregnancy, and 4) those claiming that abusing substances during pregnancy was evidence of the severity of the problem. Information from court proceedings, as presented in the court ruling, was also used in some cases. Cases would typically include several types of arguments, but categorization was based on an assessment of the most prominent claim. A few cases could not be classified, mostly due to missing data.

\section{Results}

As shown in Table 1, applications highlighting the welfare of both the woman and the fetus were most common (43\%). The second most common category (28\%) consisted of applications where the focus was clearly on the fetus. In $17 \%$ of the applications, the pregnancy was mentioned in a neutral manner without being highlighted or commented on any further. In 9 cases (8\%) the main argument was that abusing substances during pregnancy was an indicator of the severity of the problem and the urgent need for care. In the remaining cases it was not possible to make any categorization, or the relevant documents were missing.

\section{Table 1}

Categories of arguments in social services' applications for compulsory care in cases involving pregnant substance abusers

\begin{tabular}{lc}
\hline & Percent $(\boldsymbol{N}=\mathbf{1 1 6})$ \\
\hline There is a risk for the woman's or the woman's and fetus'/child's health & 43 \\
Primarily for the sake of the fetus/child & 28 \\
Neutral mentioning & 17 \\
Substance abuse during pregnancy is an indication of the severity of the problem & 8 \\
Other/missing & 4 \\
\hline
\end{tabular}

\section{Arguing the Case for Both Mother and Fetus}

Arguments in this category relate to the risks for the woman and the fetus, both present and future. First, the pregnancy itself poses immediate health risks for the mother (e.g., "L's body is exposed to a double health risk when abusing substances during pregnancy"; "the midwife is concerned about J's health and the risk of placental abruption. Her blood values are also very low"). There may also be a need for protection against harms not directly related to the substance abuse or the pregnancy itself (e.g., "A has revealed that the father-to-be has kicked her in the abdomen twice in order to induce a miscarriage"). References may similarly be made to the woman's severe mental health problems and violent behavior, increasing the risk of self-harm as well as harm to the fetus. In another case there is worry that the client's epileptic seizures may hinder supply of oxygen to the placenta.

Second, and more importantly, substance abuse during pregnancy may cause future medical and social harm to both parties (e.g., "the social consequences for S and her expected child are devastating”). Apart from possible brain damage and congenital malformations, the harms to the child are usually referred to in very general terms ("health," "well-being," "development”). The social consequences are usually about losing custody of the child or not being able to parent properly. However, the most commonly mentioned potential harm to health is deterioration of the woman's mental health (e.g., "By [dropping out of 
treatment again] she will expose her physical, but above all her mental, health to serious harm by the risk that her child will be born with severe and irrevocable harm due to her substance abuse").

\section{Arguing the Case for the Fetus}

Table 2 summarizes the 32 cases in which the health and welfare of the fetus/child were the primary concern. As can be seen, there is also often mention of the consequences for the woman herself even here, but the categorization is based on a total assessment of the primary cause for concern as reflected in the application. The women in this category were aged 20-45, and the mean gestational age was 5.6 months. Policies and documents regarding substance (alcohol) abuse and pregnancy often focus on Fetal Alcohol Syndrome Disorder (European Commission, 2006; Popova \& Chambers, 2014; World Health Organization, 2014). However, there are few such references in the care applications. Most likely this reflects the fact that only a few of these women have alcohol as their single primary drug. We do, however, recognize use of selected passages from legislative documents. Sometimes government reports are cited directly (cases 2, 3) but more often their content is referenced but not cited (i.e., continued substance abuse during pregnancy is an indication of the severity of the situation and the urgent need for care, and the risk that the woman's mental health may be seriously impaired if she becomes the cause of "serious and irrevocable harm to the child" [cases 3, 6, 18,
31]). Direct or indirect references to research are also made (cases 17, 19), but more often the claims are more straightforward (i.e., the client needs to be incarcerated to ensure sobriety through the remainder of the pregnancy, mainly for the sake of the child). In case 32 the application has a seemingly neutral mentioning of the client being 7 months pregnant. However, documents from the court hearing revealed that this was in fact the primary motive for commitment.

It is also worth noting that the commitment process at times seems to be dependent on whether the woman is intending to keep the child or not. In case 24 it turned out the woman was not pregnant after all, and the application was revoked. One case was withdrawn after the client had an abortion (case 29), and in case 30 the court officer learns that the social services will not proceed if the client decides to have an abortion.

\section{Neutral Mentioning of the Pregnancy}

This category is somewhat contentious, as the mere mentioning of the pregnancy means that it is seen as relevant in some way. "Neutral" therefore simply means that it is presented as background information and not elaborated on in any particular direction (e.g., " $F$ is pregnant," "she is 3 months pregnant," " $\mathrm{C}$ is also pregnant”).

Table 2

Main arguments in applications for commitment primarily for the sake of the fetus/child, by gestational age, primary and secondary drugs

\begin{tabular}{|c|c|c|c|c|}
\hline Case & Main arguments in application & $\begin{array}{l}\text { Months } \\
\text { pregnant }\end{array}$ & $\begin{array}{l}\text { Primary } \\
\text { drug }\end{array}$ & Other drugs \\
\hline 1 & $\begin{array}{l}\text { Evident risk of destroying her own as well as the coming child's life. Five } \\
\text { months pregnant, which adds another dimension to the case as the expected } \\
\text { child must be guaranteed an environment as free of alcohol and drugs as } \\
\text { possible. }\end{array}$ & 5 & Alcohol & \\
\hline 2 & $\begin{array}{l}\text { Extensive description of harmful effects of alcohol on the fetus. "Through her } \\
\text { actions, client is exposing herself to the risk of causing severe and irrevocable } \\
\text { harm to the fetus and thereby imposing harm to her own mental health." } \\
\text { References are made to government bill, and to public inquiry report from } \\
\text { 1981/82. }\end{array}$ & 4 & Alcohol & \\
\hline 3 & $\begin{array}{l}\text { Her alcohol abuse entails a significant risk of harm to the unborn child; partly } \\
\text { limiting growth, partly Fetal Alcohol Syndrome. References made to guidelines } \\
\text { from National Board of Health and Welfare from 1997, describing how a } \\
\text { pregnant woman who cannot refrain from substance abuse exposes the fetus to } \\
\text { danger. Also reference to SOU 1981/82; continued abuse of substances can } \\
\text { hardly be seen as normal for a pregnant woman, thereby an indication of the } \\
\text { severity of the problem, and that there is risk of harm to the woman's mental } \\
\text { health. "Outpatient care is not deemed to be sufficient to treat such extensive } \\
\text { substance abuse during pregnancy.” }\end{array}$ & 6 & Alcohol & \\
\hline 4 & $\begin{array}{l}\text { Client is } 32 \text { weeks pregnant. Has been living in a tent with her heroin-abusing } \\
\text { boyfriend during the pregnancy. "Did not seek contact with the outreach team }\end{array}$ & 8 & Heroin & $\begin{array}{l}\text { Benzodiazepines, } \\
\text { methadone }\end{array}$ \\
\hline
\end{tabular}
till beginning of her 6th month of pregnancy. Denies substance abuse. Because she is an advanced stage of pregnancy she is also exposing the expected child to harm." 


\begin{tabular}{|c|c|c|c|c|}
\hline Case & Main arguments in application & $\begin{array}{c}\text { Months } \\
\text { pregnant }\end{array}$ & $\begin{array}{l}\text { Primary } \\
\text { drug }\end{array}$ & Other drugs \\
\hline 5 & $\begin{array}{l}\text { Client is immediately apprehended based on the fact that she is "actively } \\
\text { abusing substances, is pregnant and that the fetus can come to harm if client } \\
\text { does not receive care. A court ruling cannot be awaited, considering that the } \\
\text { health state of the fetus may be seriously harmed." }\end{array}$ & 7 & Amphetamine & $\begin{array}{l}\text { Heroin, } \\
\text { benzodiazepines }\end{array}$ \\
\hline 6 & $\begin{array}{l}\text { Extensive commenting on the pregnancy. Client's partner has reported her to } \\
\text { social welfare office. Her continued substance abuse despite pregnancy is a } \\
\text { primary topic. “ [Because] she is exposing her child to serious danger } \\
\text { compulsory care is relevant.” Main arguments are risk for the child, and for her } \\
\text { own mental health. }\end{array}$ & 6 & Amphetamine & $\begin{array}{l}\text { Sedatives, } \\
\text { alcohol }\end{array}$ \\
\hline 7 & $\begin{array}{l}\text { "Is exposing herself and the unborn child to serious danger. To guarantee } \\
\text { sobriety during the remainder of the pregnancy she needs to be in secure } \\
\text { residential care." }\end{array}$ & 5 & Alcohol & $\begin{array}{l}\text { Benzodiazepines, } \\
\text { opiates }\end{array}$ \\
\hline 8 & $\begin{array}{l}\text { Client abused medication during her last pregnancy, and child was born } 2 \\
\text { months prematurely. Currently } 7 \text { months pregnant and has relapsed into heroin } \\
\text { abuse. The pregnancy was unplanned and client was unaware of it till she was 5- } \\
6 \text { months pregnant. "Not caring about the consequences of continued substance } \\
\text { abuse, despite knowledge about the risks for the child, can hardly be seen as a } \\
\text { normal form of behavior for a pregnant woman. It is deemed that there is an } \\
\text { acute danger that client's own mental health can be harmed if she, by refraining } \\
\text { to stem her abuse of substances, becomes the cause of her child being born with } \\
\text { severe and irrevocable harms." }\end{array}$ & 6 & Heroin & Benzodiazepines \\
\hline 9 & $\begin{array}{l}\text { Reference made to specialist family unit's assessment that the substance abuse } \\
\text { may harm the fetus. }\end{array}$ & 6 & Amphetamine & $\begin{array}{l}\text { Benzodiazepines, } \\
\text { opiates }\end{array}$ \\
\hline 10 & $\begin{array}{l}\text { Reference made to doctor at maternity clinic expressing great concern about the } \\
\text { health of the unborn child as abusing substances during pregnancy may cause } \\
\text { serious harm. }\end{array}$ & 5 & Alcohol & $\begin{array}{l}\text { Amphetamine, } \\
\text { hashish }\end{array}$ \\
\hline 11 & $\begin{array}{l}\text { "The main aim of the care is that the client is guaranteed drug free conditions." } \\
\text { The commitment is revoked as soon as the child is born. }\end{array}$ & 6 & Alcohol & \\
\hline 12 & $\begin{array}{l}\text { "The client is expecting in about a month, but the child may come any time now. } \\
\text { The client may have cut down on her drug consumption during the pregnancy, } \\
\text { but a pregnant woman exposes her child to risks through any use of drugs. It is } \\
\text { not acceptable to use drugs in order to soothe pregnancy-related aches, which } \\
\text { has been client's explanation for drug use during the pregnancy... By abusing } \\
\text { substances she is exposing herself and her child to substantial health risks. If she } \\
\text { continues to abuse substances she risks seriously harming her social situation } \\
\text { and having to part with her child." }\end{array}$ & 8 & Hashish & Amphetamine \\
\hline 13 & $\begin{array}{l}\text { The client is immediately apprehended with consideration of the fact that she is } \\
\text { pregnant. }\end{array}$ & 6 & Heroin & Benzodiazepines \\
\hline 14 & $\begin{array}{l}\text { Investigation was induced because "client is pregnant and has tested positively } \\
\text { for drugs." }\end{array}$ & 3 & Amphetamine & $\begin{array}{l}\text { Benzodiazepines, } \\
\text { hashish }\end{array}$ \\
\hline 15 & $\begin{array}{l}\text { The investigation largely focuses on the pregnancy. Social welfare office finds } \\
\text { that she needs to be apprehended in order to stay free of drugs during the } \\
\text { pregnancy. The goal will be fulfilled when the child is born. }\end{array}$ & 5 & Heroin & $\begin{array}{l}\text { Amphetamine, } \\
\text { benzodiazepines }\end{array}$ \\
\hline 16 & "The interest of the child comes first." & 6 & Heroin & Cocaine \\
\hline 17 & $\begin{array}{l}\text { In connection with immediate apprehension, no mention is made of pregnancy. } \\
\text { In a more extensive investigation later on there is mention that she has found to } \\
\text { be pregnant after being taken in at institution. "According to current research } \\
\text { drug abuse during pregnancy entails great risk of deformation and other fetal } \\
\text { harm.” }\end{array}$ & 2 & Amphetamine & \\
\hline 18 & $\begin{array}{l}\text { "The client has abused heroin throughout a large part of the pregnancy despite } \\
\text { being informed about the risks of fetal harm. She is placing her own needs in }\end{array}$ & 6 & Heroin & $\begin{array}{l}\text { Methadone, } \\
\text { amphetamine }\end{array}$ \\
\hline
\end{tabular}




\begin{tabular}{ll}
\hline Case & \multicolumn{1}{c}{ Main arguments in application } \\
\hline 19 & $\begin{array}{l}\text { "The aim of the commitment to care is that the client shall be provided with help } \\
\text { and support to stay free of drugs during the pregnancy. . . . The client has insight } \\
\text { into the consequences of her substance abuse for the fetus. Despite this, she }\end{array}$ \\
& lacks the ability to stay drug free on her own hand. ... The child may be born \\
with serious and irrevocable harms caused by her substance abuse. As client is 8 \\
months pregnant, emphasis should be put on the fact that the risk of harm from \\
heroin abuse is greatest in the last part of the pregnancy. It is highly important \\
that client gets necessary support to stay drug free during rest of pregnancy." \\
"It is 3 years since client was pregnant last. Now, as then, she continues to use \\
drugs, she didn't accept voluntary care, and it ended in a compulsory \\
commitment. The present situation is similar. Client has lately avoided any \\
contact with the social services and maternity care. ... Our assessment is that \\
client lacks ability to act in a way that protects the child and even herself from \\
evident risks due to her substance abuse (including risk for her mental health if \\
she becomes the cause of serious and irrevocable harm to the child. ... Plan for \\
care; to keep client drug free during the remainder of the pregnancy."
\end{tabular}

21 Plan for care during commitment: "That client receives care and treatment for her substance abuse. That care is provided throughout the pregnancy and that her ability to take care of the child is assessed while admitted.”

22 Investigation induced after report from special family unit. In application for care in July/August she is 28 weeks pregnant and the last documentation of substance abuse was in April. "She is exposing her own as well as her expected child's health to risk of harm.”

23 "The consequences of the suspected substance abuse can be devastating for the client as a new mother. ... The reason an investigation was induced was that client was pregnant and could not, despite her condition, refrain from drugs. . . . Client has now given birth to her child. As the undersigned, responsible social welfare officer, finds that the goal has been achieved, it is suggested that commitment to compulsory care is revoked.”

24 The day after she was admitted to the institution, the social welfare officer asked that the client do a pregnancy test. "Due to the fact that the doctor's certification states there are no grounds for compulsory care, we find no grounds to go forward with an application. Moreover, a negative pregnancy test shows there is no risk of harm to someone else's life. Hence, the social welfare office hereby revokes its application for commitment to compulsory care with immediate effect."

25 Doctor at specialist maternity clinic reports to social welfare office - is worried about client and the expected child. Social welfare initiates an investigation. After attempting voluntary measures, an application for commitment is made with reference to the pregnancy.

26 Reference to pregnancy as reason for application for compulsory care.

"Client should be cared for at [institution] till the child is born, before being placed in compulsory community care.”

28 "Client lacks insight into the consequences her substance abuse may have for her child. It is of greatest importance that client is helped to keep away from drugs during remainder of pregnancy. This should be done within the framework of compulsory care.”

29 "Client taken in acutely due to destructive abuse of heroin and at the same time 20 weeks pregnant. Client was placed in detoxification and had a late abortion. During detoxification client was positive about the voluntary treatment alternatives presented to her, therefore the chairman of the social welfare board decided to lift the decision on immediate apprehension [the day after the abortion].”

\begin{tabular}{ccc}
$\begin{array}{c}\text { Months } \\
\text { pregnant }\end{array}$ & $\begin{array}{c}\text { Primary } \\
\text { drug }\end{array}$ & Other drugs \\
\hline 7 & Heroin & Hashish
\end{tabular}

\begin{tabular}{|c|c|c|}
\hline 5 & Amphetamine & $\begin{array}{c}\text { Heroin, } \\
\text { benzodiazepines }\end{array}$ \\
\hline 7 & $\begin{array}{l}\text { Benzodiazepine } \\
\mathrm{s}\end{array}$ & $\begin{array}{l}\text { Heroin, } \\
\text { methadone }\end{array}$ \\
\hline 7 & Heroin & $\begin{array}{l}\text { Amphetamine, } \\
\text { benzodiazepines }\end{array}$ \\
\hline $\begin{array}{l}\text { Not } \\
\text { regnant }\end{array}$ & Heroin & $\begin{array}{c}\text { Hashish, } \\
\text { benzodiazepines }\end{array}$ \\
\hline 5 & Sedatives & $\begin{array}{l}\text { Amphetamine, } \\
\text { benzodiazepines }\end{array}$ \\
\hline 2 & GHB & $\begin{array}{l}\text { Amphetamine, } \\
\text { heroin }\end{array}$ \\
\hline 8 & Heroin & $\begin{array}{l}\text { Amphetamine, } \\
\text { benzodiazepines }\end{array}$ \\
\hline 7 & Heroin & Benzodiazepines \\
\hline
\end{tabular}

$5 \quad$ Heroin Benzodiazepines 


\begin{tabular}{|c|c|c|c|c|}
\hline Case & Main arguments in application & $\begin{array}{l}\text { Months } \\
\text { pregnant }\end{array}$ & $\begin{array}{l}\text { Primary } \\
\text { drug }\end{array}$ & Other drugs \\
\hline 30 & $\begin{array}{l}\text { Official note from court: "Called the social welfare officer. She met client today } \\
\text { and got the chance to inform her about the application for commitment, } \\
\text { something she had not been able to do previously. Client told her she has } \\
\text { decided to have an abortion. ... If client goes through with what she has said } \\
\text { and has the abortion, [the social welfare office] will revoke the application.” } \\
\text { Note from staff at institution following telephone conversation with responsible } \\
\text { social welfare officer; "she expressed uncertainty about whether they would go } \\
\text { forward with application for regular commitment, pointing to the fact that client } \\
\text { was going to have an abortion and that she was not in that bad a state." }\end{array}$ & 4 & Amphetamine & Hashish \\
\hline 31 & $\begin{array}{l}\text { "Pregnant and has not established contact with a maternity clinic, which in itself } \\
\text { is very disquieting." Mention is also made of the client's plan to have an } \\
\text { abortion. }\end{array}$ & 3 & Opiates & Benzodiazepines \\
\hline 32 & $\begin{array}{l}\text { "7 months pregnant. Recently relapsed after } 4 \text { months abstinence." The } \\
\text { seemingly neutral mentioning is, in association with arguments presented orally } \\
\text { in court, interpreted by the court as the main reason why client is being } \\
\text { committed. Court rejects application. }\end{array}$ & 7 & Alcohol & \\
\hline
\end{tabular}

\section{An Indication of the Severity of the Problem}

In several cases-even many years later-the social services cite government reports from the early 1980s in which the criteria for commitment were discussed. The application may include explicit references to legislative documents or use similar phrases or lines of reasoning (e.g., "The fact that she continues to misuse substances during her pregnancy can hardly be regarded as normal behavior . . . and probably reflects that the substance abuse and drug addiction has become so severe that she is in urgent need for care in order to break free from this"; "despite her pregnancy and that she has a 15 month old child, she has relapsed into intravenous drug abuse”). Another example of unusual or unacceptable behavior is "consistently refuting proposals" of residential care even after learning she was pregnant.

\section{Discussion}

Although social work is surrounded by law, the helping professionals are rarely trained to "speak to the law" (Rooney, 2009; Staaf, 2004). If an application for compulsory care is driven mainly by concern for the fetus, social workers may choose to be frank in their concern and hope the courts will let it pass. Alternatively, the social workers must attempt to reframe the case to achieve the outcome of compulsory care. Three strategies seem to prevail in such instances. First, mother and child may be presented as one entity and care is needed for the sake of both. Second, substance abuse during pregnancy is an indication of just how severe the problem is and how imperative the need for care is. Third, keeping within the limits of the legislation, it may be suggested that the woman's future mental health is at risk if she becomes the cause of severe and irrevocable harm to the child. In other words, while politicians have attempted to change "law in the books," street-level bureaucrats have developed a "law in action," allowing pregnant substance abusers to be committed to care even when the primary concern is the unborn child.
Why, then, do street-level bureaucrats make the effort to prepare these cases, despite the transaction costs? A tentative answer may be sought in Rooney's (2009) legalethical matrix: in one category the legal and the ethical overlap; the second category comprises intrusions that may be legal but hardly ethical; the third category comprises ethical but illegal measures; and the fourth category comprises measures that are neither legal nor ethical. Social workers may, in these cases, use their discretionary power to pursue an action they find to be ethical, albeit not strictly legal. This does not necessarily reflect "pro-life" sentiments, which generally have little support in Sweden and probably even less so among social workers. In a survey of the background and career patterns of social work students in 1972 and 1992, it was found that relatively many were from working-class homes and both cohorts had an overrepresentation of left-party sympathizers (Burman, 2001). In its formal reply to the proposed legislative amendments concerning pregnant substance abusers, the Association of Directors of Social Welfare Services (2009) advised against the amendments, claiming that the existing legislation was sufficient and "is applied, to ensure that substance abusing pregnant women get care." Sykes and Matza (1957) describe how juvenile delinquents may very well subscribe to the "dominant normative system" (p. 669) and find strategies to neutralize, excuse, or explain their actions rather than promoting opposing ideologies or subcultures. Social workers are generally not strong supporters of coercion in social work, but faced with such challenging cases they may find themselves dodging principles to which they otherwise subscribe.

A more prosaic explanation for their actions might be that the women are already "in the system" and therefore the threshold is lower for a new commitment. In almost half of these cases the woman had previously been committed to compulsory care for substance abuse, and in 51\% of cases the woman already had a child under the age of 18 . This means many were already deeply involved with the social services. 
There are several limitations to this study that also translate into proposals for future research. First, the study does not include instances where an application did not materialize. A prospective research design, including interviews with social workers and court officials, would provide a better understanding of the decisions and "non-decisions" being made. Second, the study is based on secondary data with greatly varying comprehensiveness. Following oral court proceedings would also provide valuable insights in how arguments are conveyed (Jacobsson, 2004). Third, information on the contexts in which discretion was practiced was not available.

Faced with the conflict between a woman's rights and the welfare of a coming child, some social workers will choose the latter. As a coping strategy it does not necessarily mean a reduced workload for the street-level bureaucrat.

\section{Acknowledgments}

I would like to acknowledge colleagues at the National Board of Institutional Care, especially Linda Weding, for invaluable assistance and for supporting the initial project. Apart from constructive reviewer comments, helpful suggestions were provided by participants at the Thematic Meeting of the Kettil Bruun Society in Melbourne in September 2014, where a previous version was presented.

\section{References}

Association of Directors of Social Welfare Services. (2009). Yttrande 14 augusti 2009 till Socialdepartementet över promemorian om Insatser för en alkohol- och narkotikafri graviditet (Ds 2009:19) [Statement on August 14, 2009, to the Ministry of Social Affairs on the memorandum on Measures for an alcohol and drug free pregnancy (Ds 2009:10)]. Retrieved from http://www.socialchefer.se/ default.asp?id=978

Blomqvist, J., Palm, J., \& Storbjörk, J. (2009). 'More cure and less control' or 'more care and lower costs'? Recent changes in services for problem drug users in Stockholm and Sweden. Drugs: Education, Prevention, Policy, 16, 479-496. doi:10.3109/09687630802640305

Burman, G. (2001). Socionomstuderanden 1972 och 1992. En jämförande studie mellan antagna till utbildningen i Stockholm [Social work students in 1972 and 1992. A comparative study of admitted students in Stockholm] (Master's thesis). Stockholm University, Sweden. Retrieved from http://gunburman.se/ magisteruppsats.html

Comprehensive Strategy for Alcohol, Drugs, Doping, and Tobacco Policy Bill 2010 (No. 2010/11:47).

Compulsory Care for Substance Abuse Bill 1981 (No. 1981/82:8)

Compulsory Care for Adult Substance Abusers Bill 1987 (No. 1987/88:147).
Durrant, J. E. (1999). Evaluating the success of Sweden's corporal punishment ban. Child Abuse \& Neglect, 23, 435-448. doi:10.1016/S0145-2134(99)00021-6

Eduards, M. (1991). Toward a third way: Women's politics and welfare policies in Sweden. Social Research, 58, 677-705.

Ekendahl, M. (1999). Att välja vårdform - En studie inom fyra kommuners öppna alkoholvård [Choosing forms of care - A study within outpatient alcohol services in four municipalities]. Stockholm, Sweden: National Board of Health and Welfare.

Ekendahl, M. (2004). Omöjlighetens praktik - en studie av socialtjänstens LVM-handläggning [The impossible practice - A study of social services casework concerning compulsory care]. In Swedish Government Official Report 2004:3 Tvång och förändring [Coercion and change] (pp. 167-301). Stockholm, Sweden: Fritzes.

European Commission. (2006). An E.U. strategy to support member states in reducing alcohol related harm. Brussels, Belgium: Communication from the Commission to the Council, the European Parliament, the European Economic and Social Committee, and the Committee of the Regions.

Freeman, M. (Ed.) (2014). The future of children's rights. Lejden, Netherlands: Brill Nijhoff.

Jacobsson, M. (2004). Konflikten som inte blir av. Argumentation och kommunikation i LVMförhandlingar [The conflict that does not materialize. Reasoning and communication in negotiations on compulsory commitment of substance abusers]. In Swedish Government Official Report 2004:3 Tvång och förändring [Coercion and change] (pp. 61-125). Stockholm, Sweden: Fritzes.

Johansson, K.-O. (2001). Om LVM-vårdens utveckling under 1990-talet samt uppföljning av 25 LVManmälda personer under år 1999 [On the development of compulsory care during the 1990s and follow-up of 25 persons who were assessed for compulsory care in 1999]. Stockholm, Sweden: Social Services Administration, Stockholm Municipality.

Kelly, M. (1994). Theories of justice and street-level discretion. Journal of Public Administration Research and Theory, 4, 119-140.

Lipsky, M. (1980). Street-level bureaucracy. Dilemmas of the individual in public services. New York, NY, United States: Russel Sage Foundation.

Lundgren, L., Brännström, J., Armelius, B.-Å., Chassler, D., Morén, S., \& Trocchio, S. (2012). Association between immigrant status and history of compulsory treatment in a national sample of individuals assessed for drug use disorders through the Swedish public welfare system. Substance Use \& Misuse, 47, 67-77. doi:10.3109/10826084.2011.628736

Ministry of Social Affairs 2009 (No. Ds 2009:19).

National Board of Health and Welfare. (2007a). Gravida kvinnor med missbruk och barn som lever i familjer med missbruksproblem [Pregnant substance abusers and children living in families with substance abuse]. Stockholm, Sweden: Author.

National Board of Health and Welfare. (2007b). Nationella riktlinjer för missbruks- och beroendevården 
[National guidelines for substance abuse and addiction services]. Stockholm, Sweden: Author.

Nilssen, E. (2007). Politics, profession and law: The legal development of compulsory intervention towards substance abusers in Scandinavian social law. Scandinavian Political Studies, 30, 20-37. doi:10.1111/j.1467-9477.2007.00171.x

Palm, J. (2009). "Man får inte supa ihjäl sig enligt svensk lagstiftning!” Svenska socialarbetares tal om bruket av tvångsvård ["You're not allowed to drink yourself to death according to Swedish law!" - Swedish social workers on how they use compulsory treatment]. Nordic Studies on Alcohol and Drugs, 26, 277-293.

Palm, J., \& Stenius, K. (2002). Sweden: Integrated compulsory treatment. European Addiction Research, 8, 69-77.

Parliamentary Committee of Social Affairs 1981 (No. Ds S 1981:6).

Perselli, J. (1998). Fostersyn i svensk rätt [The fetus in Swedish legislation] (Doctoral thesis). Linköping University, Sweden. Retrieved from http://liu.divaportal.org/smash/get/diva2:20703/FULLTEXT01.pdf

Popova, S., \& Chambers, C. (2014). Fetal Alcohol Spectrum Disorders must be recognized globally as a large public health problem. The International Journal of Alcohol and Drug Research, 3, 1-3. doi:10.7895/ijadr.v3i1.174

Pressman, J., \& Wildavsky, A. (1984). How great expectations in Washington are dashed in Oakland. Or, why it's amazing that federal programs work at all, this being a saga of the economic development administration as told by two sympathetic observers who seek to build morals on a foundation (3rd ed.). Berkeley, California, United States: University of California Press.

Reitan, T., \& Weding, L. (2012). Gravida missbrukare inom LVM-vården (Institutionsvård i fokus 9/2012) [Pregnant substance abusers in compulsory care]. Stockholm: National Board of Institutional Care.

Rooney, R. H. (Ed.) (2009). Strategies for work with involuntary clients. New York, NY, United States: Columbia University Press.

Runquist, W. (2012). Legitimering av tvångsvård [Legitimizing compulsory care]. Malmö: Egalité.

Swedish Government Official Report 1981 (No. 1981/82:22).

Swedish Government Official Report 1987a (No. 1987:11).

Swedish Government Official Report 1987b (No. 1987:22).

Swedish Government Official Report 2005 (No. 2005:82).

Swedish Government Official Report 2011 (No. 2011:35).

Staaf, A. (2004). Analys av socialnämndernas utredningar inför ansökan om tvångsvård enligt LVM [Analysis of the social welfare boards' assessments in connection with applications for compulsory care according to the Care for Substance Abusers (Special Provisions) Act]. In Swedish Government Official Report 2004:3 Tvång och förändring [Coercion and change] (pp. 127-166). Stockholm, Sweden: Fritzes.

Storbjörk, J. (2003). Kvinnor och män i svensk missbruksbehandling [Women and men in Swedish substance abuse treatment]. Stockholm, Sweden:
Centre for Social Research on Alcohol and Drugs (SoRAD), Stockholm University.

Storbjörk, J. (2010). Vem tvångsvårdas? Utmärkande drag för tvångsvårdade respektive frivilligt vårdade personer med alkohol- och narkotikaproblem [Who is admitted to compulsory treatment? Characteristics of compulsorily and voluntarily treated persons misusing alcohol and drugs]. Nordic Studies on Alcohol and Drugs, 27, 19-46.

Sykes, G. M., \& Matza, D. (1957). Techniques of neutralization. A theory of delinquency. American Sociological Review, 22, 664-670.

Svensson, G. (2012). Högsta förvaltningsdomstolen och tvångsvården: $\quad \mathrm{Om}$ betydelsen $i$ rättssäkerhetshänseende av domstolens domar angående LVU och LVM [The Supreme Administrative Court and compulsory care: On the importance of the court's rulings for rule of law in cases concerning Care of Young Persons Act and Care of Substance Abuse (Special Provisions) Act]. Stockholm, Sweden: Norstedts juridik.

Tham, H. (1995) Drug control as a national project: The case of Sweden. Journal of Drug Issues, 25, 113-128.

United Nations Children's Fund (UNICEF). (2009). State of the world's children. Celebrating 20 years of the convention on the rights of the child. New York, NY, United States: Author.

Wallander, L., \& Blomqvist, J. (2005). Who “needs" compulsory care? A factorial survey of Swedish social workers' assessments of clients in relation to the Care of Substance Abusers (Special Provisions) Act. Nordic Studies on Alcohol and Drugs, 22, 63-85.

World Health Organization. (2014). Guidelines for the identification and management of substance use and substance use disorders in pregnancy. Geneva, Switzerland: Author. 